\title{
Trivial matters, Cincinnati style
}

\author{
By Mary Ellen Rutledge Elsbernd \\ Collection Development Librarian \\ Northern Kentucky University
}

\section{Amaze the natives with the depth of your Cincinnati knowledge at ACRL's Fifth National Conference in April.}

K consummate pastime of many Americans and librarians. As ACRL's fifth National Conference is only a few short months away, the following tidbits will whet your appetite for a taste of Cincinnati trivia.

\section{A.K.A.'s}

"Losantiville" - The first name given to Cincinnati in 1788 by John Filson.

"Porkopolis"-Renowned for its pork packing, by 1845 Cincinnati had sausaged more than 250,000 hogs.

"Queen City of the West"-By 1830 Cincinnati had become a significant western river town with great industrial promise.

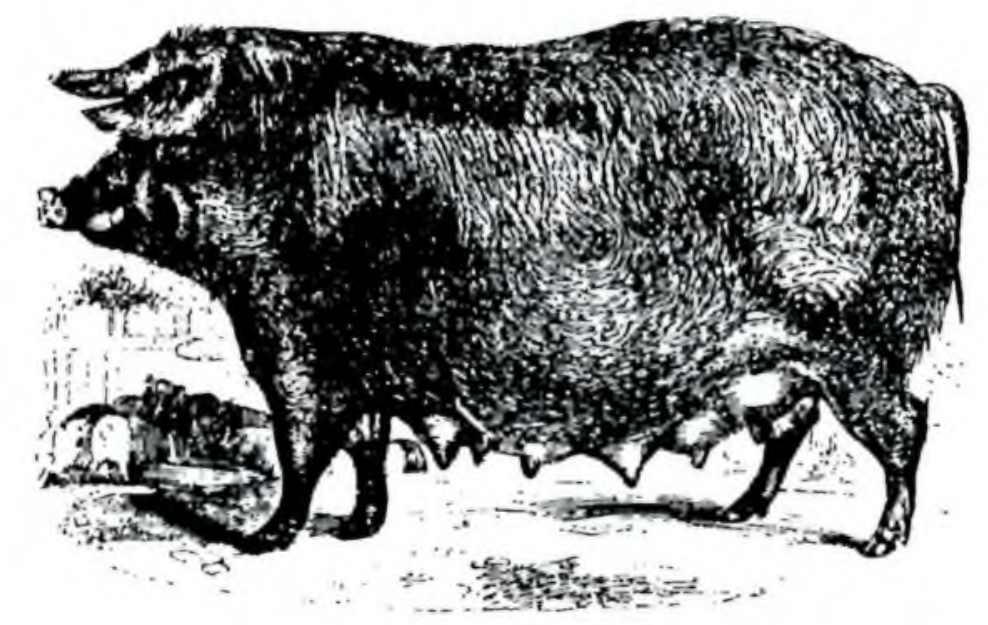

\section{Wealth}

Cincinnati's first millionaire and patron of the arts, Nicholas Longworth (1782-1863), "paid the second highest property taxes in the U.S. while only in his forties."

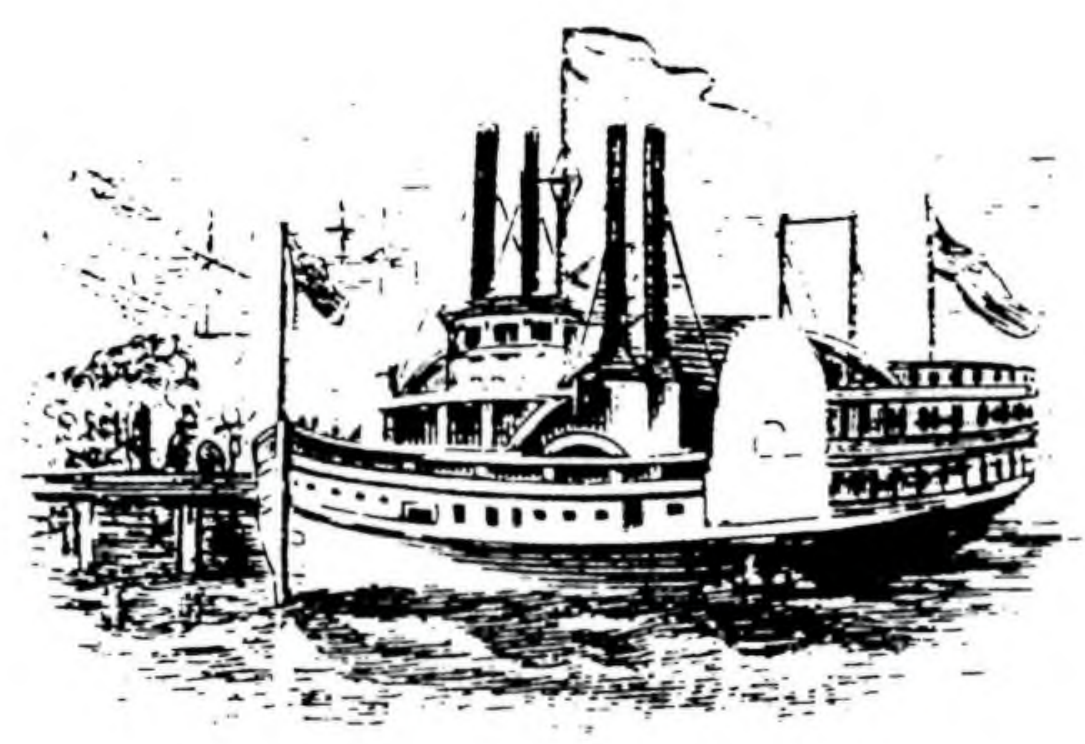

\section{Captured in poetry}

"And this song of the Vine,

This greeting of mine,

The winds and the birds shall deliver

To the Queen of the West

In her garlands dressed,

By the banks of the Beautiful River."

—“Catawba Wine," Henry Wadsworth Longfellow

\section{Birthplace}

Theda Bara

Johnny Bench

Ted Turner

Stephen Spielberg

Tyrone Power

Pete Rose 


\section{Hometown musicians}

Marty Balin, of Jefferson Starship ("Ride the Tiger")

Mel Carter ("Hold Me, Thrill Me, Kiss Me")

The Casinos ("Then You Can Tell Me Goodbye")

Rosemary Clooney ("Come on-a My House")

Doris Day ("Secret Love")

Carl Dobkins Jr. (“My Heart Is an Open Book”)

Bo Donaldson and the Heywoods ("Billy, Don't Be a Hero")

The Isley Brothers (“Twist and Shout")

Freddy King ("Hide Away")

The Lemon Pipers ("Green Tambourine")

Kenny Price ("Sheriff of Boone County")

Pure Prairie League ("Let Me Love You Tonight")

Roy Rogers ("Hoppy, Gene and Me")

Otis Williams and the Charms ("Ivory Tower")

\section{Firsts}

Air mail: Where mail first took to the sky via balloon, July 4, 1835.

American beer: The first American beer to pass the German quality control Reinheitsgebat was Christian Moerlein, introduced by Hudepohl in 1984.

Concrete skyscraper: Ingalls Building, 4th and Vine, 1902.

Educational television station: The first licensed educational TV station in the U.S. was WCET, 1954.

Fire fighting: First fireman's pole and the first city to establish a municipal fire department.

Music: The first municipal songfest, Saengerfest, 1849.

Professional baseball club: The Cincinnati Red Stockings, 1869.

Train robbery: America's first, on May 5, 1865, near North Bend, Ohio, when an Ohio and Mississippi passenger train was derailed by armed robbers who swarmed through the cars demanding valuables.

U.S. Jewish theological college: Hebrew Union College, 1875.

Weather report: First U.S. weather bureau established in 1869.

Yeast: First U.S. production of compressed yeast, Charles Fleischmann, 1868.

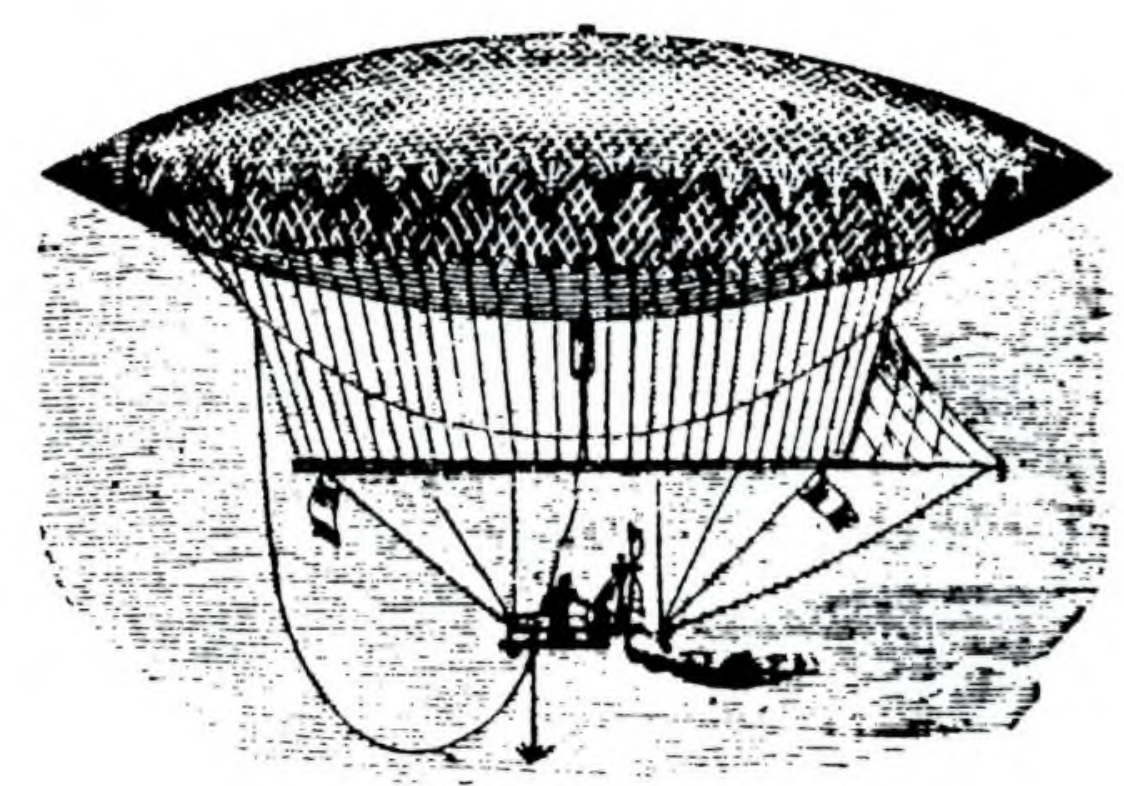

\section{Chili capital of the U.S.A}

You can have your chili five different ways in Cincinnati, which boasts the best in the East at least. One-way is plain old (Texas) chili; two-way is spaghetti topped with chili; three-way is spaghetti topped with chili and mild cheddar cheese; four-way is spaghetti topped with chili, cheese, and chopped onions. In full blossom, five-way is all of the above, plus a layer of kidney beans. Jeff Smith, "the Frugal Gourmet," professes that authentic Cincinnati chili contains cinnamon, allspice, and cocoa.

\section{Pardon me, boys}

The actual route of the Chattanooga Choo Choo ran from Cincinnati.

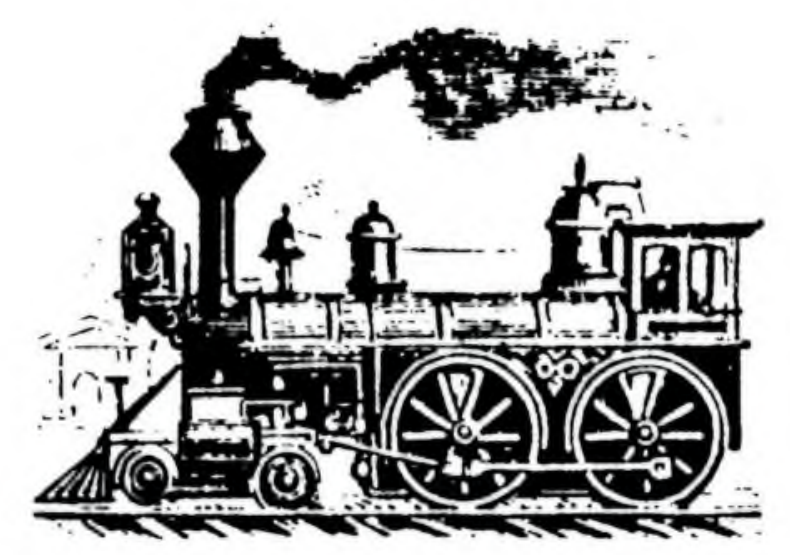

\section{Clothes horse}

By 1860 Cincinnati was manufacturing one-half of all the ready-to-wear garments available in the western market.

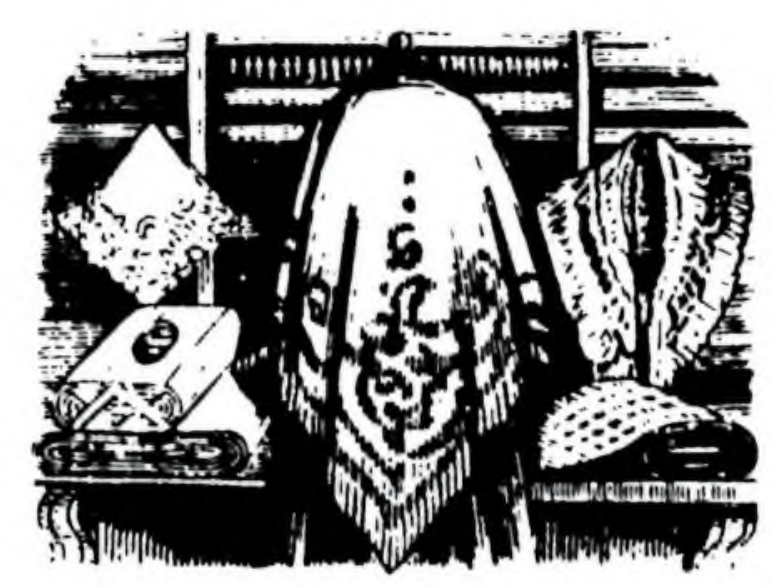

\section{Women's work}

Maria Longworth Nichols Storer (1849-1932) was the first woman in the U.S. to own and operate a major industry, the Rookwood Pottery.

Margaret "Marge" Schott was the first woman to buy a major league baseball team, the Cincinnati Reds, in 1984.

Inspired by the anti-slavery movement, Harriet Beecher Stowe based her book, Uncle Tom's Cabin, on her experiences while residing in Cincinnati.

At the tender age of 24 , Josephine Johnson won a Pulitzer Prize for her first novel, Now in November.

\section{Fruit of the vine}

The popularity of Catawba wine made Ohio the number one wine-producing state in the 1860s.

Meier's Wine Cellars are one of the oldest premium wineries in the U.S. 


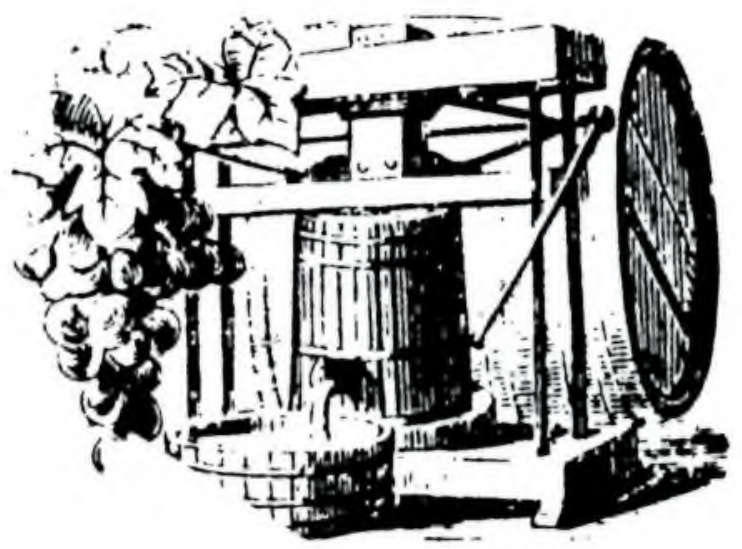

\section{Population}

By 1860 , Cincinnati was the sixth largest city in the U.S. with 115,535 citizens.

\section{In common}

What do Doris Day, Rosemary Clooney, Rod Serling, Andy Williams, the McGuire Sisters, and Fats Waller have in common? WLW, the local radio station, gave all their careers a boost. From 1934 to 1939 WLW had the most powerful broadcasting system in the world.

\section{Miss Manners is watching}

Cincinnatians learned to eat pie with a fork, thanks to Sir Alfred T. Goshorn, a leading light during the 1860s and 1870s. Sir Alfred was better known for organizing the original Cincinnati Industrial Expositions and serving as mayor of Clifton.

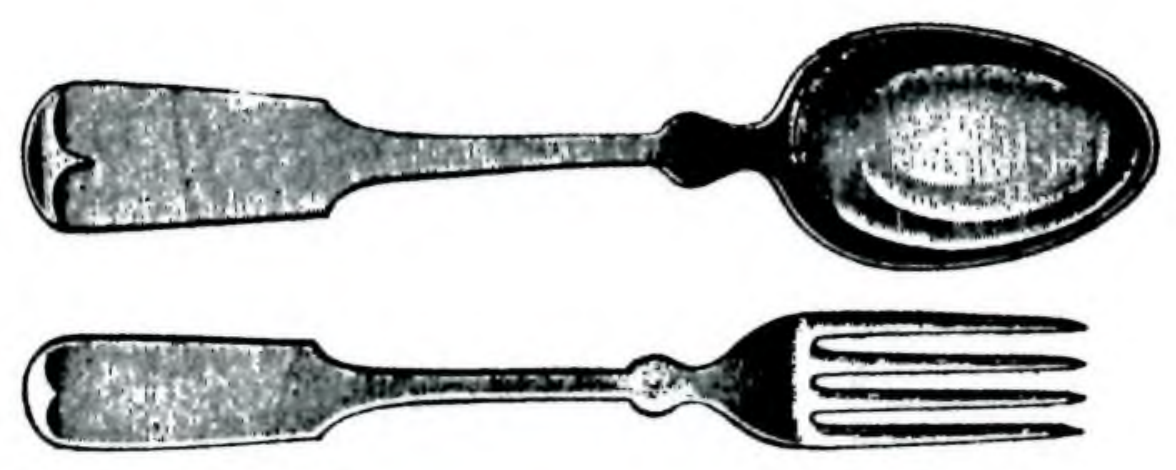

It's in the cards

The first greeting card was produced by Gibson Greeting Cards in 1850.

\section{Hey, dummy!}

The Vent Haven Museum, home for more than 600 ventriloquists' dummies, is found in nearby Fort Mitchell, Kentucky.

\section{German heritage}

More than 600,000 of the one million residents in Greater Cincinnati are of German descent.

\section{Highest, fastest, longest, baddest}

Definitely "The Beast," a roller coaster ride at King’s Island.

\section{Long overdue}

In 1823 a book on febrile disease was checked out from the University of Cincinnati Medical Library and returned in 1968.

\section{Dry bones}

Referred to as "one of the greatest graveyards of prehistoric animals ever discovered," Big Bone Lick State Park (located south of Florence, Kentucky) is the site of the ancient salt sulphur spring frequented by mammoths, mastodons, and the like.

\section{Brought to you by Proctor and Gamble}

Floating soap: Ivory, 1879.

The first all-vegetable shortening: Crisco, 1911.

Disposable diapers: Pampers, 1962.

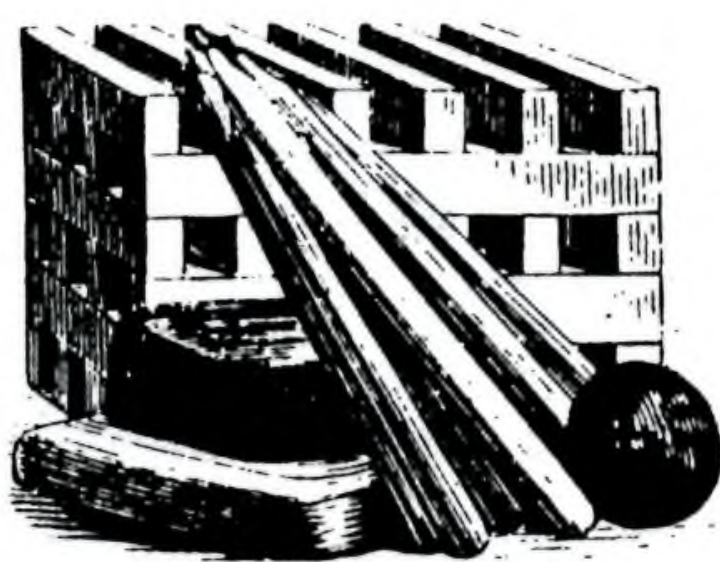

The most trivial

Ivory soap got its name from a passage in the fifth Psalm: "Thy garments smell of myrrh and aloes, and cassia out of ivory places."

\section{Squeaky clean}

Thanks to the Drackett Company, you and your household can remain squeaky clean due to such products as Drano, Vanish, Windex, Behold, Endust, Mr. Muscle, Twinkle, Renuzit, and Miracle White. Proctor and Gamble is the soap king (but more about that later).

\section{Well read}

The oldest library west of the Alleghenies is the Young Men's Mercantile Library, located on Walnut Street in downtown Cincinnati.

Cincinnati College president William McGuffey compiled the First and Second McGuffey's Readers in 1836. They were used to educate generations of Americans in the virtues of frugality, industry, and sobriety.

On the other hand, the first national convention of the Know-Nothing Party was held in Cincinnati in 1854.

\section{Bridge to the south}

Designed by John A. Roebling in 1866, the Suspension Bridge that spans the Mason-Dixon Line, is the world's longest and first suspension bridge.

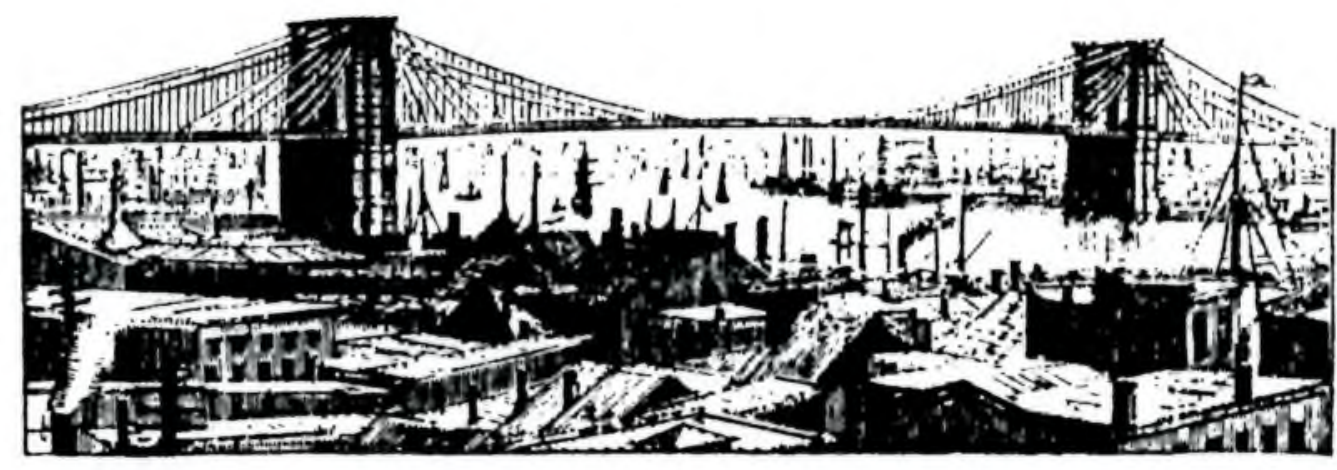




\section{The city skeleton}

A defunct subway system lies beneath the streets. In 1916 city fathers designated $\$ 600,000$ to establish a major subway system. Unfortunately the money evaporated before the project was half finished.

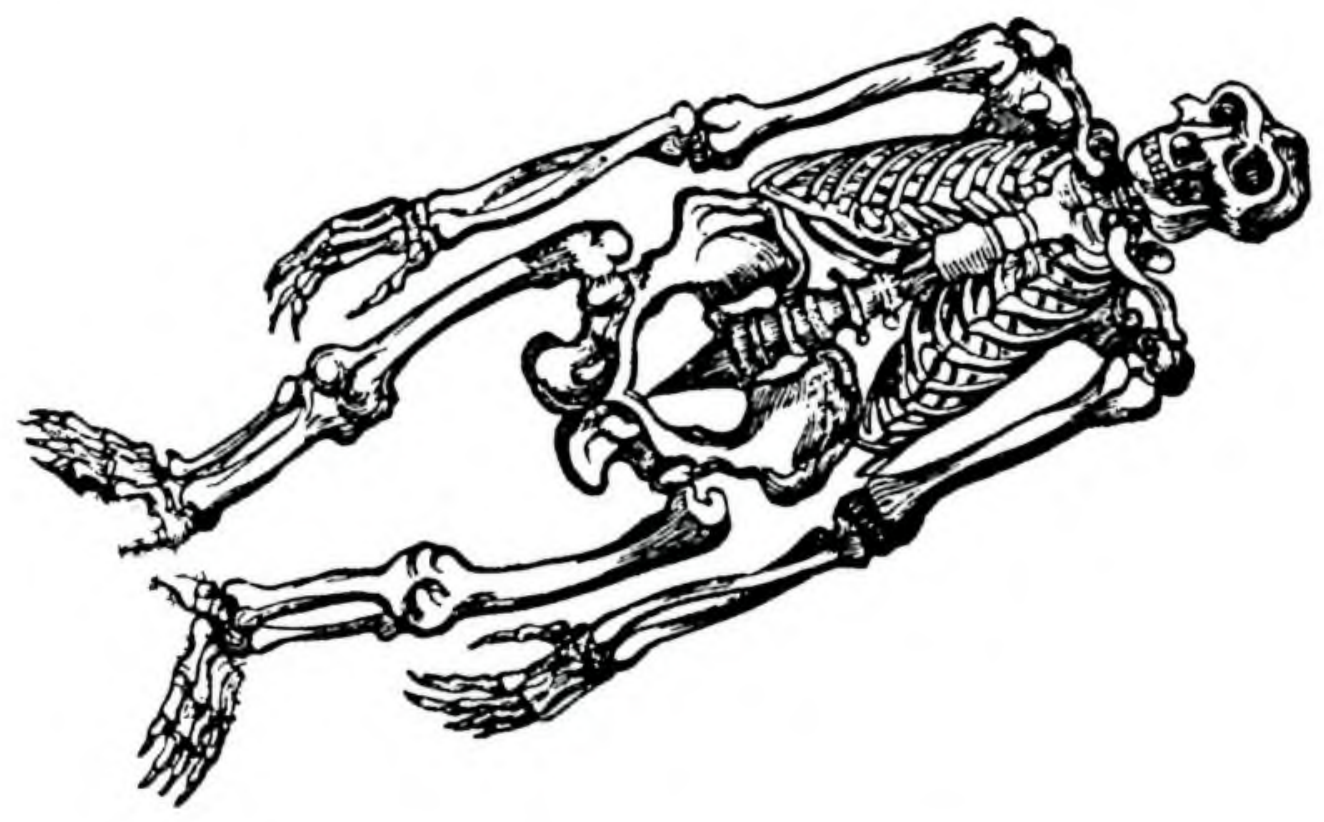

\section{The boys of summer}

The first night baseball game was held in Cincinnati on May 24, 1935-just catching up, Cubs?

\section{Guzzlin' down the brew}

By the 1890s, on the average, every man, woman and child in Cincinnati consumed 40 gallons of beer a year-24 times the national average.

On an ax-grinding temperance visit to Cincinnati in 1901, Carrie Nation was heard to exclaim: "I would have dropped from exhaustion before I had gone a block."

In 1919 Prohibition laws closed over 2,000 saloons, breweries and distilleries. The Germans and the Irish were not amused.

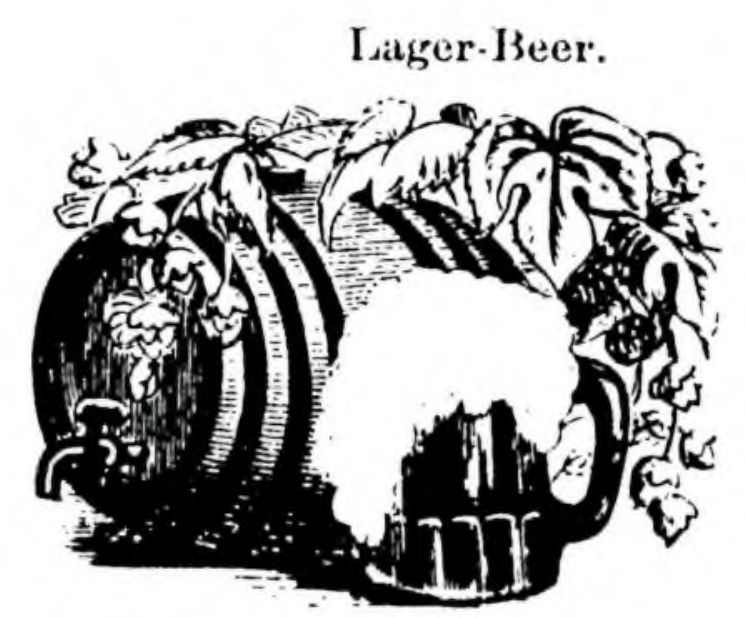

\section{Sex in cages}

A leader in breeding wild animals, the Cincinnati Zoo birthed fourteen baby black rhinos, 1959-1985.

\section{Largest, cleanest, brightest}

Coney Island's Sunlight Pool is allegedly the world's largest re-circulating pool.

\section{Cavernous}

The world's largest man-made caverncomplete with a 32-foot waterfall-can be found at the Cincinnati Museum of Natural History and Planetarium.

\section{Large}

William Howard Taft was fondly referred to as "Big Lub" by his Cincinnati boyhood chums. He was the 27th President of the United States and the only President to serve as Chief Justice of the Supreme Court.

\section{What they did first}

Stephen Foster worked in his brother's steamboat office by the river in Cincinnati. While here he composed many such favorites as "Oh Susanna!"

John Twachtman decorated window shades in some of Cincinnati's finest homes.

John James Audubon started out as a taxidermist in the Western Museum, now the Cincinnati Museum of Natural History.

Henry Farny designed circus posters in Cincinnati.

\section{Medical firsts}

Dr. Albert Sabin, inventor of the oral polio vaccine, conducted his initial mass test of the vaccine with Cincinnati school children in 1959.

Dr. Henry Heimlich discovered his "Heimlich maneuver" that saves choking victims.

The first heart-lung machine was developed at Children's Hospital Medical Center in 1952.

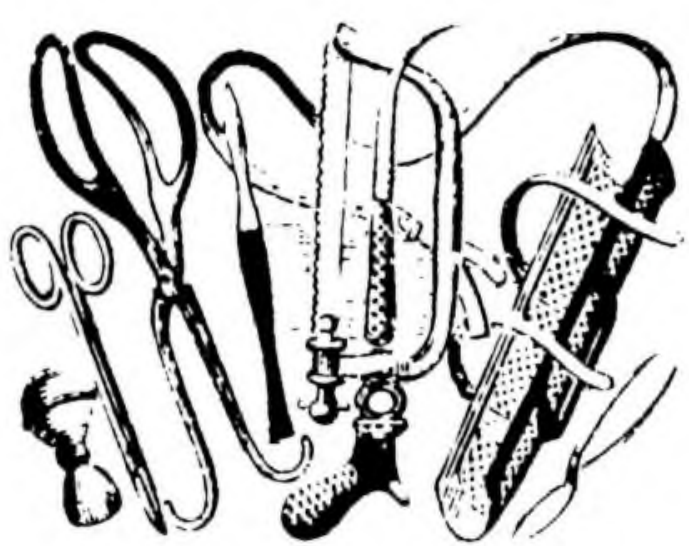

Of historic import

Four residents of Cincinnati became Presidents of the U.S.: William Henry Harrison, Rutherford B. Hayes, Benjamin Harrison, and William Howard Taft.

Leopold Stokowski conducted the Cincinnati Symphony Orchestra from 1909-1912.

\section{Service to the mentally ill}

I am interested in contacting librarians who would like to develop a discussion group or membership activity group on library services to persons who are or have been mentally ill, and who are not institutionalized. There is much discussion about this service, but apparently no group within ALA has it as a focus. If you are interested, contact: Linda Lucas, Professor, University of South Carolina, Columbia, SC 29208; (803) 777-3858. I hope to arrange a planning meeting for the 1989 Annual Conference in Dallas. - Linda Lucas. 